\title{
Physical efficiency of girls with conservatively treated idiopathic scoliosis
}

\author{
Jacek Durmala*1 and Krystyna Dobosiewicz ${ }^{2}$
}

\author{
Address: ${ }^{1}$ Department of Rehabilitation, Medical University of Silesia, Katowice, Poland and ${ }^{2} \mathrm{GWSH}$, Katowice, Poland \\ Email: Jacek Durmala* - jdurmala@gcm.pl \\ * Corresponding author
}

\author{
from 4th International Conference on Conservative Management of Spinal Deformities \\ Boston, MA, USA. 13-16 May 2007 \\ Published: 12 October 2007 \\ Scoliosis 2007, 2(Suppl I):S3 doi:I0.II86/I748-7|6I-2-SI-S3
}

This abstract is available from: http://www.scoliosisjournal.com/content/2/SI/S3

(c) 2007 Durmala and Dobosiewicz; licensee BioMed Central Ltd.

\section{Objective}

The aim of the study was to estimate the influence of conservative treatment on physical efficiency in girls with idiopathic scoliosis (IS). Physical efficiency was estimated by maximal minute oxygen uptake, ventilatory anaerobic threshold (VAT), and maximal workload.

\section{Study design}

A study group consisting of eighty-seven girls with IS, aged ten to seventeen years (mean $13.5 \pm 1.61$ years) with thoracic $(\mathrm{n}=49)$ and double major scoliosis $(\mathrm{n}=38)$, was compared with a control group of seventy-seven healthy girls. The mean Cobb angle among the subjects with IS was $31 \pm 16.2$ degrees (range 11-75 degrees).

\section{Methods}

A subgroup of sixty-four girls was treated conservatively using 3D exercises by Dobosiewicz and a second subgroup of twenty-three girls were treated using 2D (symmetric) corrective exercises [1,2]. A subgroup of twenty-six girls with IS who received 3D exercises by Dobosiewicz ( $\mathrm{n}$ $=18$ ) or symmetric exercises $(n=8)$, were tested before and after treatment. The ergospirometry test was performed using cycle ergometer. Percentage of predicted values was used for analysis.

\section{Results}

All girls with IS were classified within the normal range of predicted values of maximal minute oxygen uptake, VAT and maximal workload. Among twenty-six girls tested before and after treatment, a statistically significant increase in the value of VAT occurred during intensive hospital rehabilitation (Table 1).

\section{Conclusion}

The exercise efficiency of girls with IS, conservatively treated by physiotherapy, is normal.

Table I:

\begin{tabular}{|c|c|c|c|}
\hline \multirow[t]{2}{*}{ Percentage of predicted value of } & \multicolumn{2}{|c|}{ Girls with IS treated using } & \multirow[t]{2}{*}{ p value } \\
\hline & Dobosiewicz's method & symmetric exercises & \\
\hline Maximal minute oxygen uptake & 98 & 90.5 & 0.033 \\
\hline VAT & 97 & 93.3 & 0.049 \\
\hline Maximal workload & 101 & 93.9 & 0.038 \\
\hline
\end{tabular}




\section{References}

I. Durmala J, Dobosiewicz K, Kotwicki T, Jendrzejek H: Influence of asymmetric mobilisation of the trunk on the Cobb angle and rotation in idiopathic scoliosis in children and adolescents. Ortop Traumatol Rehabil 2003, 5:80-85.

2. Dyner-Jama I, Dobosiewicz K, Niepsuj K, Niepsuj G, Jedrzejewska A, Czernicki K: Effect of asymmetric respiratory exercise therapy on respiratory system function; evaluation using spirometric examination in children with idiopathic scoliosis. Wiad Lek 2000, 53:603-610. Polish

Publish with Bio Med Central and every scientist can read your work free of charge

"BioMed Central will be the most significant development for disseminating the results of biomedical research in our lifetime. " Sir Paul Nurse, Cancer Research UK

Your research papers will be:

- available free of charge to the entire biomedical community

- peer reviewed and published immediately upon acceptance

- cited in PubMed and archived on PubMed Central

- yours - you keep the copyright

Submit your manuscript here:

http://www.biomedcentral.com/info/publishing_adv.asp 